Landslides (2018) 15:773-782

DOI 10.1007/s10346-018-0952-x

Received: 7 August 2017

Accepted: 24 January 2018

Published online: 16 February 2018

(C) The Author(s) 2018

This article is an open access publication
Lorenzo Solari · Federico Raspini · Matteo Del Soldato · Silvia Bianchini · Andrea Ciampalini · Federica Ferrigno - Stefano Tucci - Nicola Casagli

\section{Satellite radar data for back-analyzing a landslide event: the Ponzano (Central Italy) case study}

Abstract In this manuscript, an integrated strategy that exploits both phase and amplitude features of satellite SAR (synthetic aperture radar) images and ground data is proposed for deriving the deformation field induced by a complex landslide that affected part of the village of Ponzano (Abruzzi Region, Central Italy). The February 12, 2017, landslide was triggered by the combined effects of intense rainfalls and snowmelt that saturated the slope. The SqueeSAR algorithm was applied to two C-band SAR datasets, composed by Radarsat- 2 and Sentinel-1 images, spanning a nineyear time interval before the landslide occurrence. Moreover, the amplitude information carried by two TerraSAR-X images, acquired immediately before and after the event, was exploited to derive the total displacement generated by the landslide movement by means of the RMT (rapid motion tracking) algorithm. The obtained results allow describing the landslide behavior before and after its failure. In particular, the back-monitoring analysis shows that the landslide was already slowly moving, with deformation rates increasing from the Radarsat-2 to the Sentinel1 monitored periods, 10 years before its complete mobilization. The landslide failure of February 2017 produced maximum displacements of about $10 \mathrm{~m}$ in some sectors of the affected area. The registered deformation rates and the localization of the maximum displacements areas were confirmed by field data, collected during a field campaign and a helicopter recognizance of the damaged areas, both performed after the event.

Keywords InSAR · Landslide monitoring · SqueeSAR · Rapid motion tracking

\section{Introduction}

Italy is one of the European countries with the highest percentage of landslide prone landscape (13\%, according to Nadim et al. 2006). The slope movements are responsible for a considerable annual economic loss for the Nation, estimated $0.3-0.4 \%$ of the gross domestic product (Canuti et al. 2004). In addition to the economical aspect, 8000 people were killed by landslide phenomena in the twentieth and twenty-first centuries and, in the same period, 200,000 people lost their house for the damages connected to the landslides activity (Salvati et al. 2015).

Civil protection authorities (CPAs) are involved in preventing landslide hazard and in managing emergencies that derive from landslide events. Satellite-based earth observation (EO) techniques guarantee a data coverage with high temporal and spatial density of measurements, ideally suited for slow-moving landslide monitoring (Tralli et al. 2005). In this framework, the use of synthetic aperture radar (SAR) images for deriving the phase information related to the ground displacements is nowadays commonly used in the civil protection practices and as a valuable tool for monitoring pre- and post-event movements (Corsini et al. 2006; Canuti et al. 2007; Farina et al. 2007; Pagliara et al. 2014; Raspini et al. 2017; Solari et al. 2017).
In the last 20 years, several algorithms for SAR images analysis have been developed to derive ground displacements, exploiting multi-interferogram approaches (Crosetto et al. 2016). Among them, two InSAR (interferometric synthetic aperture radar) techniques, PSInSAR (Ferretti et al. 2001) and its evolution SqueeSAR (Ferretti et al. 2011), have been widely exploited for the detection, mapping, definition of the state of activity, and monitoring of slow-moving landslide (Meisina et al. 2008; Herrera et al. 2011, 2013; Bianchini et al. 2013; Lu et al. 2014; Notti et al. 2014; Bianchini et al. 2015a, b; Oliveira et al. 2015; Raspini et al. 2015; Bardi et al. 2016; Calvello et al. 2016; Ciampalini et al. 2016; Béjar-Pizarro et al. 2017).

In this paper, we take advantage from the multi-temporal capabilities of an interferometric analysis to characterize the prefailure deformation scenario and calculate the total displacement induced by the complex landslide that affected the Ponzano hamlet of the Civitella del Tronto municipality in the Teramo Province (Abruzzi region, Central Italy). The landslide mainly resulted from the snow melting due to the increment of the temperature during January 2017, combined with intense rainfalls in January and February 2017. Thirty-two buildings were involved by the landslide movement resulting in the evacuation procedures of the inhabitants.

For the characterization of the landslide, two different types of SAR processing techniques were chosen to (i) investigate the prefailure movements, exploiting the SqueeSAR analysis of C-band (RADARSAT-2 and Sentinel-1) SAR images, covering the period March 2003-February 2017 and focusing mainly on the monitoring of buildings and infrastructures; (ii) analyze the surface change during the main landslide deformation phase exploiting the amplitude signal through the rapid motion tracking (RMT) technique (Paradella et al. 2015; Raspini et al. 2015) applied to X-band TerraSAR-X SAR images acquired immediately before and after the landslide failure.

\section{Study area}

Ponzano is one of the hamlets of the Civitella del Tronto municipality in the northern sector of the Teramo Province, close to the border with the Marche Region (Fig. 1). It is located in a hilly area at an average elevation of $360 \mathrm{~m}$ a.s.l. The landslide affects a E-SE facing gentle relief ranging from 400 to $190 \mathrm{~m}$ a.s.l. The slope angle ranges from 4 to $12^{\circ}$. The area is extensively covered by crops and pastures with scattered woods and small groups of houses.

\section{Geological and geomorphological background}

The morphology of the area is strictly related to the Mio-Pliocene compressive tectonics that formed the mountainous belt of the Abruzzi region (Mattei et al. 1995). From Lower Pleistocene, the area was characterized by a compressional tectonic phase that ended in the Upper Pleistocene and that was associated with a 


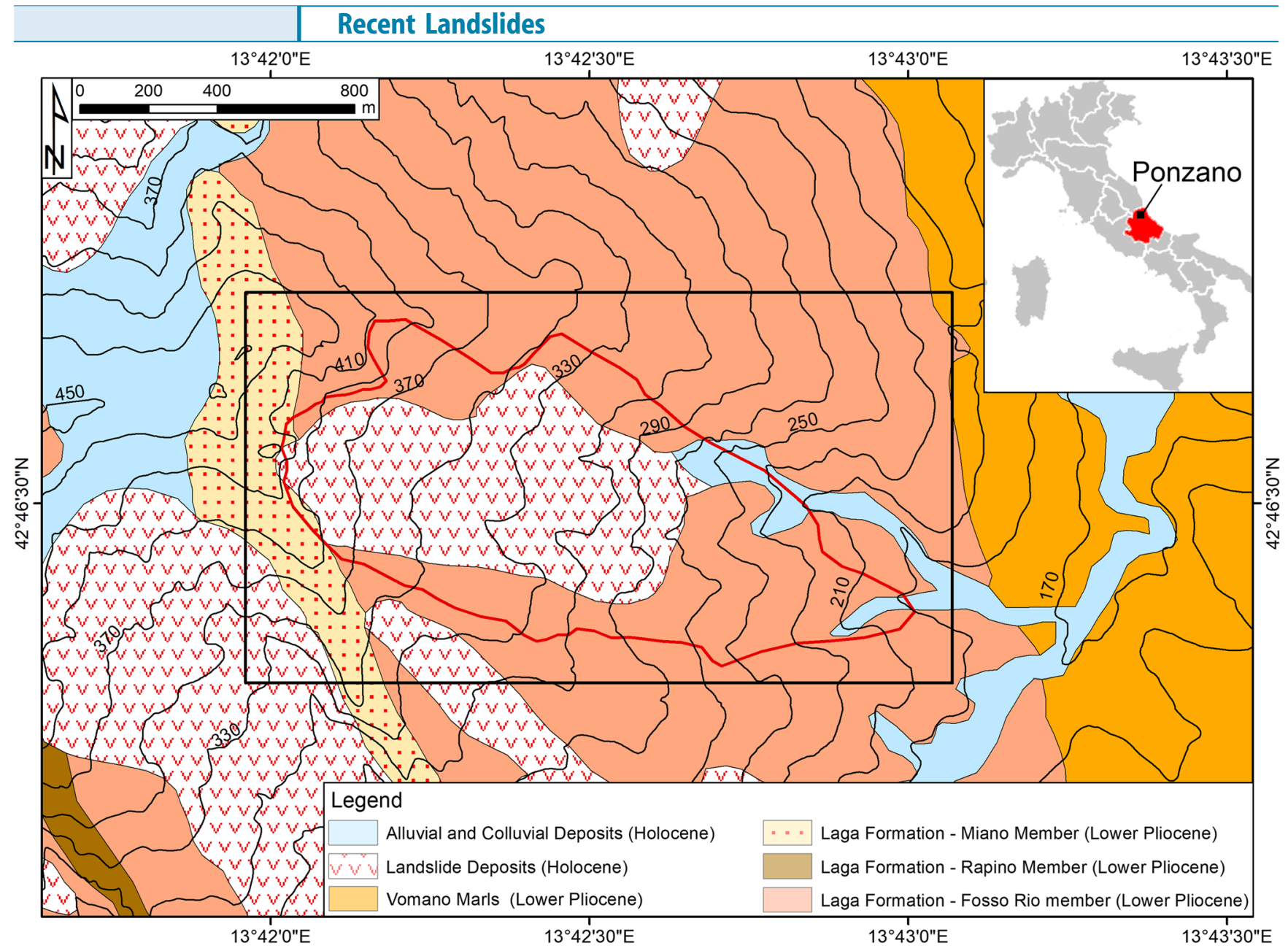

Fig. 1 Geographic location and geological sketch of the area of interest. The black rectangle indicates the landslide area. The geological map (nominal scale 1:50,000) is derived from the CARG (Italian Geological Map) project available online (http://www.isprambiente.gov.it/Media/carg/339_ TERAM0/Foglio.html). The red contour represents the landslide boundary

general uplift and eastward tilting of the structures (Nisio et al. 1996). In the study area, the thrust-related tectonic motion produced an eastward monoclinal morphology characterized by gentle slopes with maximum angle of $10^{\circ}$ (Cantalamessa and Di Celma 2004). These hilly reliefs are represented by isolated ridges, mainly formed by Meso-Cenozoic calcareous terrains, and by mesa or cuesta morphologies imposed on arenaceous-pelitic and peliticarenaceous turbidites (Centamore et al. 1991).

In the investigated area a marine siliciclastic succession (Late Miocene-Early Pleistocene) and continental sediments (Early Pleistocene-Holocene) crop out (Fig. 1). In particular, the marine succession is represented by the Upper Miocene-Early Pliocene siliciclastic turbidites of the Laga Formation, here represented by the Fosso Rio, Rapino, and Miano Members. The Laga Formation is a foredeep flysch sequence composed by a repeated alteration of arenaceous turbidites, marls, and pelagic clays with variable thickness (Speranza et al. 1997). Of this sequence, the Fosso Rio Member represents a pelitic-arenaceous association, formed by gray marls with sporadic fine-grained sandstones, up to $100 \mathrm{~m}$ thick; whereas, Rapino and Miano Members represent two different arenaceous-pelitic associations. The first one is characterized by a regular alternation of arenites, marly-clays beds, and massive sandstones, 80 to $100 \mathrm{~m}$ thick; the second one is composed by a thickening upward succession of siliciclastic turbidites passing to a pelitic facies at the top of the sequence that has an overall thickness of $75 \mathrm{~m}$ (Brozzetti et al. 2010). The Fosso Rio and Rapino Members crop out in the landslide area (red rectangle in Fig. 1).

In the area of interest, alluvial/colluvial and landslide Holocene deposits are also present. The latter found on the slope affected by the movement investigated in this paper.

For the area of interest, two landslide inventories are available: the Hydrogeological Setting Plan of the Abruzzi Region and the IFFI (Inventory of Landslide Phenomena in Italy) catalogue; both inventories record the presence of a quiescent earth flow.

\section{Landslide characterization}

On 12th February 2017, a landslide involved an area of around 60 ha on the SE facing slope of the Ponzano village (Fig. 2).

The landslide, with an estimated volume of about $7 \times 10^{6} \mathrm{~m}^{3}$, was triggered by the combination of two factors:

- the saturation of the slope after the direct and slow infiltration of water related to the snow melting due to the increase of 


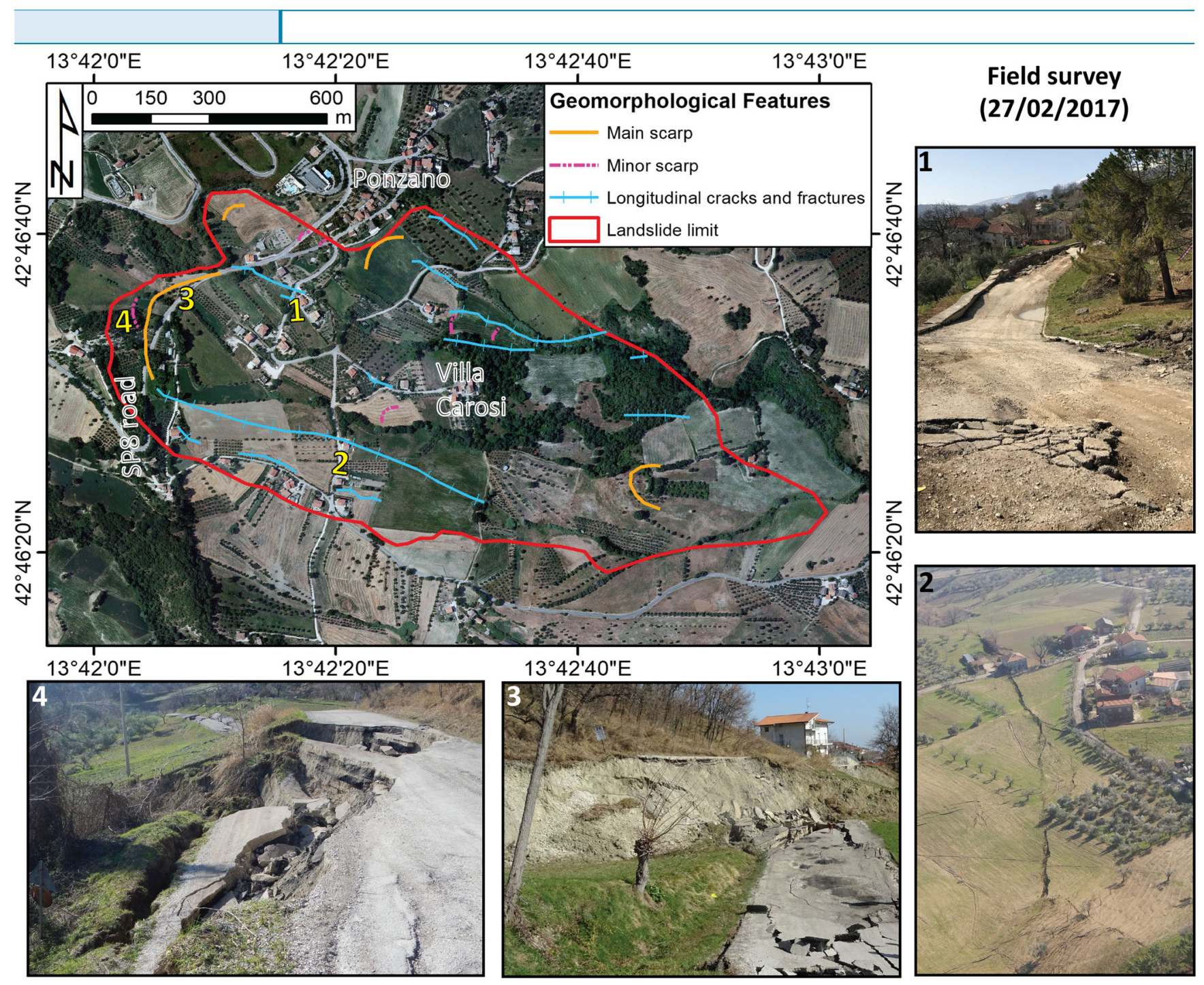

Fig. 2 The 12th February 2017 landslide. In the insets, field evidences are reported: (1) retaining wall collapse SW than the Ponzano village, and (2) main lineament of fractures along the southern border of the landslide. Photographs taken during the helicopter recognition: (3) main scarp and (4) secondary scarp

temperature between the end of January 2017 and the beginning of February 2017. In particular, January 2017 registered an average temperature of $-1.4^{\circ}$; whereas, in the first 10 days of February 2017, this value increase to $8^{\circ}$. The maximum thickness of the snow cover in this area, during the month of January, was estimated in $100-120 \mathrm{~cm}$;

- intense rainfalls. During February 2017, the Civitella del Tronto rain gauge ( $3 \mathrm{~km}$ westward from Ponzano) registered a cumulated rainfall of $87.3 \mathrm{~mm}$, slightly higher than the mean monthly precipitation for this part of the Abruzzi region that is equal to $60 \mathrm{~mm}$ (Vergni et al. 2016). In particular, the rain gauge recorded, between 6 th and 1oth February, a cumulative value of $81 \mathrm{~mm}$, representing the $93 \%$ of the total rainfall of February 2017 (Fig. 3). Moreover, a cumulative rainfall of $77 \mathrm{~mm}$ was registered in the last part of January 2017 (21-24/01/2017).

The landslide is a complex movement (using the terminology defined by Varnes 1978) in which two major components can be recognized: (i) rotational sliding affecting the upper and crown portion of the landslide, in proximity of the Provincial Road SP8 (see Fig. 2 for the location); (ii) an earth flow-like geometry in the central and toe portion of the landslide, characterized by a rupture surface estimated $15 \mathrm{~m}$ below the ground level. The landslide registered a maximum velocity, during its paroxysmal phase, of 4-5 m/day, classifying the movement as "moderate" (velocity between $1.8 \mathrm{~m} / \mathrm{h}$ and $13 \mathrm{~m} / \mathrm{month}$ ), according to Cruden and Varnes (1996).

Following the landslide failure, the Italian Civil Protection Department defined a restricted area, almost coincident with the landslide perimeter, in which 32 private houses recorded serious damage. As a result, about 100 people had to be moved out. In particular, the restricted area is subdivided into (i) complete residency interdiction because of the extension and severity of the damage (purple polygons in Fig. 4). People that lived in this area have to be relocated; (ii) temporary interdiction (blue polygons in Fig. 4). Some buildings located in correspondence of the landslide limits recorded only minor damage, thus the end of the 


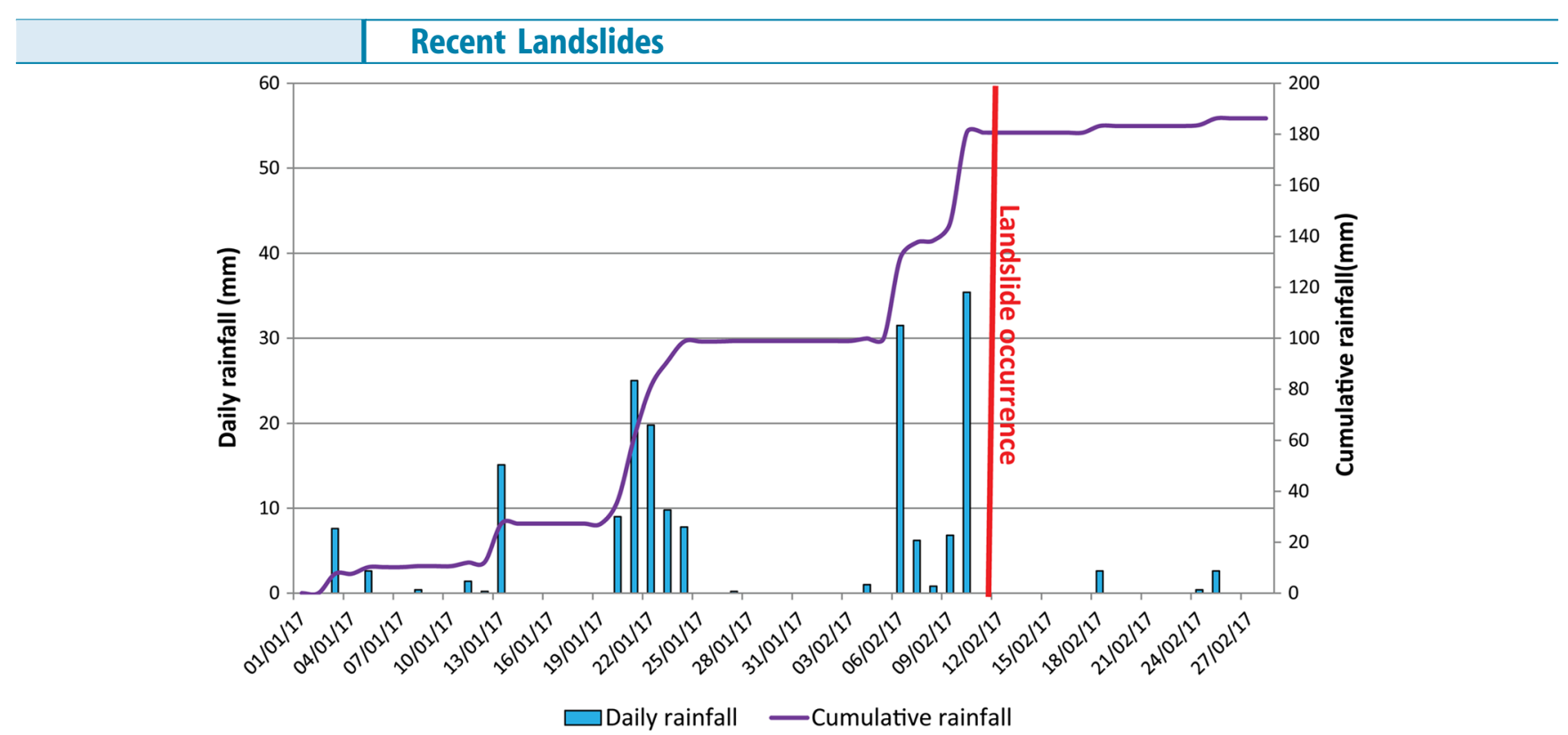

Fig. 3 Rainfall recorded during the months of January and February 2017 at the Civitella del Tronto rain gauge

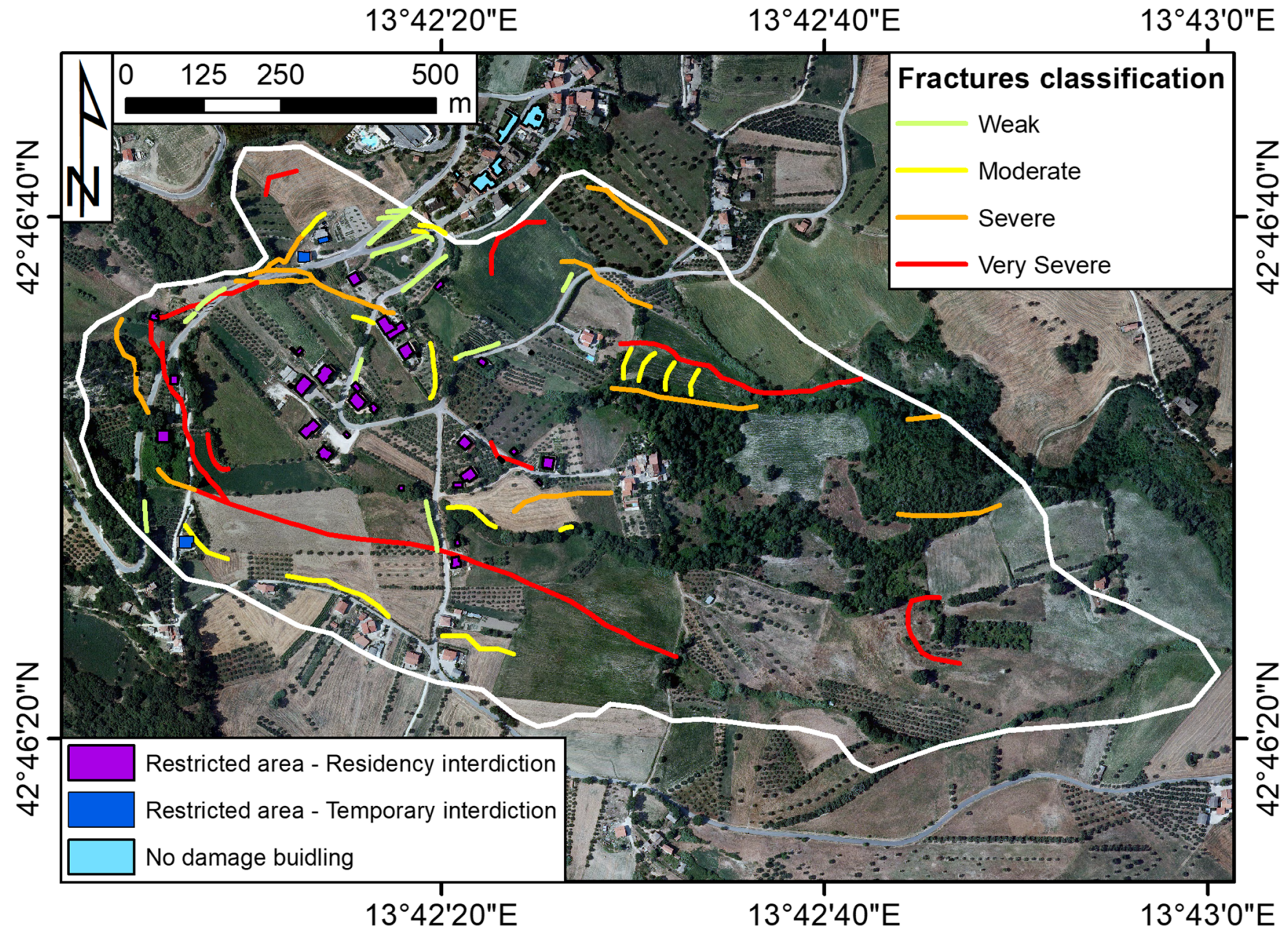

Fig. 4 Restricted buildings and classification of the fracture systems (as defined by Del Soldato et al. 2017) generated by the 12 th February 2017 landslide. The white contour represents the landslide perimeter, as defined during ground surveys 
interdiction has to be decided after a period of structural monitoring of the buildings.

The phenomenon caused the interruption of the main road access of the village, the Provincial Road SP8, that connects Ponzano with Civitella del Tronto. The road displays severe damages for a length of approximately $300 \mathrm{~m}$. The damage associated with the ground movement also made unusable the secondary road that connects Ponzano with Villa Carosi (Fig. 2).

A few days after the event, a field survey was performed to verify the on-site conditions, focusing especially on the damage affecting buildings and roads, preferential target of the multiinterferometric analysis. This survey was combined with a helicopter survey of the damaged area a few days later. In Fig. 2, some examples of ground deformation are shown. The main scarp appears as a steep surface, nearly vertical in some points, that almost follow the track of the SP8 road, 10 to $100 \mathrm{~m}$ uphill (Fig. 2-inset 3). In this sector of the landslide, other secondary scarps were found, especially along the provincial road (Fig. 2inset 4). In the central sector of the landslide, some mainly linear ground fissures and lateral scarps, 1-1.5 $\mathrm{m}$ high, run along the landslide with a maximum length of $700 \mathrm{~m}$ (Fig. 2-inset 2); these fractures delimitate the southern limit of the movement and caused severe damage to the private houses. A 3-m translation of an entire two floors building, that led to the complete disruption of the foundation structures, was documented in one case.

Figure 4 shows a severity classification of the main fracture systems detected during the field and helicopter surveys. This classification, firstly presented by Del Soldato et al. (2017), is specifically designed for evaluating landslide-induced fractures and building damage. It is based on the morphological characteristics of the fracture (opening, length, etc....) and on the type of surface involved (bare ground, vegetated surface, roads, etc....). The four classes system ranges between weak (thin cracks on roads and sidewalks) and very severe (extensive ground cracking with scarps and counterscarps associated with distorted or tilted buildings). For a complete explanation of the classification, we refer to Del Soldato et al. (2017).

Only few information are available about the recent activity of the landslide, provided by the Municipality of Civitella del Tronto. In particular, the local authorities reported how, in the last 10 years, some of the buildings that were completely disrupted by the February 2017 landslide already recorded serious damages. Some of these buildings correspond to the restricted area defined after the February 2017 event (Fig. 4). In addition, the local authorities mentioned that three inclinometers were installed, back in 2003, in the upper portion of the February 2017 landslide. In just few years, the slow motion of the landslide led to the rupture of the inclinometric instrumentation at the depth ranging between 13 and $16 \mathrm{~m}$ below surface, in accordance with the hypothesis of the February 2017 landslide surface.

\section{SAR data analysis}

In this work, C-band Radarsat-2 (RST) and Sentinel-1 (SNT) images were used as input for a multi-interferometric analysis, specifically performed by means of the SqueeSAR approach (Table 1). Moreover, the amplitude information derived from 2 TerraSAR-X (TSX) images was exploited to obtain the deformation field induced by the landslide using the RMT technique.

\section{SqueeSAR analysis}

The RST and SNT images were analyzed by means of the SqueeSAR algorithm that represents the technological evolution of the PSInSAR technique (Ferretti et al. 2001). The measurement points derived from a PSInSAR analysis are defined on the basis of a selection process applied to those image pixels showing a temporal stability of the radar signal (low temporal and geometrical decorrelation). The output of this type of analysis is PS (permanent scatterers) points that correspond to man-made targets. In order to exploit the information retrieved from rocky or nonvegetated areas that registered partially coherent benchmarks not selectable through the PSInSAR process, the SqueeSAR technique was developed (Ferretti et al. 2011). This approach allows selecting not only the point-wise coherent scatterers (PS) but also the DS (distributed scatterers) points that typically correspond to homogeneous areas as bare soils or non-cultivated areas. The use of this type of analysis allows considerably increasing the number of measurement points (MP) in areas with low urban density, as in the proposed case study (Bellotti et al. 2014; Notti et al. 2014; Bianchini et al. 2015a, b; Casagli et al. 2017; Raspini et al. 2017). Ferretti et al. (2011) reported that the SqueeSAR algorithm is able to increase of one order of magnitude the number of MP, enhancing at the same time the signal-to-noise ratio of the single measurement and so improve the quality of the time series. The deformation detected by using this approach is the projection of the real movement along the line of sight (LOS) of the sensor and shows negative sign for movements away from the sensor (color scale ranging from yellow to dark red) or positive sign for those toward the sensor (color scale ranging from light blue to blue). The values of LOS velocity displayed in green color are the ones within the stability interval that represents an estimation of the accuracy of the measurements, calculated on the basis of the standard deviation of the interferometric datasets.

\section{Rapid motion tracking analysis}

The rapid motion tracking is an amplitude-based technique that is ideally suited for detecting and measuring the displacement rates that exceed those measurable with a standard multiinterferometric approach (Raspini et al. 2015). In fact, the maximum displacement detectable between two acquisitions is equal to $\lambda / 4$, where $\lambda$ is the wavelength of the radar signal, 1.4 and $0.7 \mathrm{~cm}$ for C- and X-band sensors, respectively (Crosetto et al. 2016). Considering the annual rate, the displacement threshold is equal to $\lambda / 4$ over the revisiting time of the sensor $(21.3,25.7$, and $42.6 \mathrm{~cm} /$ year for RST, TSX, and SNT respectively). The RMT algorithm allows tracking changes between two acquisitions of a SAR satellite directly working on the amplitude information contained in the images. The offset, i.e., the component of the displacement vector along the range and azimuth directions, is calculated by performing a standard cross-correlation analysis on the two overlapping SAR images (Raspini et al. 2015). The precision of this analysis, based on the speckle tracking, is in the order of $1 / 5$ oth to1/ 2oth of an image pixel (De Zan 2014) and depends on the coherence of the image, the dimension of the investigated area (in terms of number of pixels), and on the signal-to-noise ratio (Raspini et al. 2015). In this case, a pixel patch of 50 pixels was used to calculate the amplitude offset, resulting in a precision of $2-3 \mathrm{~cm}$ (Paradella et al. 2015). This value represents the theoretical inaccuracy of this technique; however, in densely vegetated areas, 
Recent Landslides

Table 1 Summary table of the main characteristics of the SAR dataset used as input for the PSI and RMT analysis

\begin{tabular}{|c|c|c|c|c|c|}
\hline Satellite & Band & Orbit & Incidence angle & Number of images & Monitored period \\
\hline \multirow[t]{2}{*}{ Radarsat-2 } & \multirow[t]{2}{*}{$\mathrm{C}(5.4 \mathrm{GHz} ; 5.6 \mathrm{~cm})$} & Ascending & $32^{\circ}$ & 84 & $04 / 03 / 2003-20 / 03 / 2009$ \\
\hline & & Ascending & $36^{\circ}$ & 75 & $15 / 04 / 2003-14 / 03 / 2009$ \\
\hline \multirow[t]{2}{*}{ Sentinel-1 } & \multirow[t]{2}{*}{$\mathrm{C}(5.4 \mathrm{GHz} ; 5.6 \mathrm{~cm})$} & Ascending & $39^{\circ}$ & 77 & $20 / 01 / 2014-18 / 02 / 2017$ \\
\hline & & Descending & $36^{\circ}$ & 101 & 07/10/2014-23/02/2017 \\
\hline TerraSAR-X & X (9.6 GHz; $3.1 \mathrm{~cm})$ & Ascending & $42^{\circ}$ & 2 & 10/02/2017-21/02/2017 \\
\hline
\end{tabular}

possible co-registration errors can further increase the inaccuracy value (Bamler and Eineder 2005). In this work, the RMT algorithm was applied to two TSX images: one immediately before the landslide occurrence and one 9 days after the failure.

\section{Pre-failure SqueeSAR data}

The results of the SqueeSAR analysis cover the time periods between April 2003 and March 2009 (for the RST data) and from January 2014 to February 2017 (for the SNT data). It allowed constructing a nine-year time series of deformation for each measurement point. The density of PS and DS points obtained is highly influenced by the ground cover characteristics of the area of interest. In fact, the maximum density is registered above the urban areas and where small groups or single buildings are present. In some sectors of the landslide, where agricultural covers prevail, only few DS points can be found; this is especially evident in the toe sector of the landslide.

Both the RST and SNT data show general stability, defined as the velocity interval $\pm 2 \mathrm{~mm}$ /year, in the northern portion of the Ponzano village (Fig. 5a, b). This evidence is coherent with the boundary of the landslide and confirmed by the absence of damaged buildings, as described during the ground survey.

The buildings located in the central part of the landslide register the highest deformation rates in the monitored period. The deformation rates are recorded as opposite signs by the two satellite geometries, revealing the main translational horizontal component of the landslide movement. In particular, the edifices of the Villa Carosi hamlet record for the RST dataset LOS velocity equal to -23.0 and $16.0 \mathrm{~mm}$ /year in ascending and descending orbits, respectively (Fig. 5 -Sector S2). In the same area, the SNT data show peak deformation rates of -64.0 and $52.0 \mathrm{~mm} /$ year in ascending and descending orbits, respectively.

High deformation rates are also registered by a group of private houses south-western than the Ponzano village, where LOS velocities of $-20.0 \mathrm{~mm} /$ year in ascending orbit and $9.0 \mathrm{~mm} /$ year in descending orbit are measured in the time period covered by the RST data (Fig. 5-Sector S1). The SNT dataset shows an increase of the displacement rates magnitude, recording maximum values of -41.0 and $32.0 \mathrm{~mm} /$ year for the ascending and descending orbits, respectively. In both cases, the sign of the velocities vector is coherent with a movement along the slope, in the ESE direction.

Regarding the edifices located along the southern limit of the landslide, the RST data show non-significant deformations, with only few point outside of the stability threshold with maximum rates of $-5 \mathrm{~mm} /$ year in the ascending dataset. On the other hand, the SNT dataset recorded a great increase of the deformation rates that reach values higher than $\pm 20 \mathrm{~mm} /$ year $(35$ and $-22 \mathrm{~mm} /$ year for descending and ascending orbits, respectively). These velocity values correspond to zones with the most documented damage to the buildings.

\section{Time series of deformation}

The multi-interferometric analysis allows extracting not only the value of mean velocity for each measurement point but also the time series of deformation that describes the evolution of the displacement in the entire acquisition period. A time series highlights abrupt changes in the deformation trend (accelerations or decelerations) as well as seasonal variations and non-linear components (Tomás et al. 2016). The recognition of a sudden acceleration is very helpful for the data interpretation and for the definition of possible pre-failure precursors.

The time series of deformation of the most representative measurement points falling into the three sectors in which the landslide has been subdivided are shown in Fig. 6.

The sector S1 (Fig. 6a) exhibits an increase of the deformation rate between the RST and SNT time intervals in both orbits. A clear acceleration, with magnitude higher than $200 \mathrm{~mm} /$ year, is especially evident in the descending dataset between January and April 2015. A similar trend change is not as much clear analyzing the descending dataset. Generally, the trend of both curves seems to be linear, indicating a movement constant with time, but with different magnitudes between the two SqueeSAR datasets. The same behavior is shown by the sector $\mathrm{S}_{2}$ time series (Fig. 6b) with cumulative displacements slightly lower.

The sector $S_{3}$ is located in the lateral part of the landslide, near its boundary, where the longest system of fractures was mapped during the field assessment (Fig. 2). The highest trend change between the two analyzed datasets is recorded, exhibiting an increase of about one order of magnitude between the RST and SNT time periods (Fig. 6c).

\section{Post-failure rapid motion tracking analysis}

The RMT algorithm applied to two TSX images acquired immediately before and after the landslide failure allowed us to obtain reliable results for determining the deformation field induced by the landslide that, due to its magnitude, cannot be evaluated using a standard multi-interferometric approach.

The derived displacement maps (Fig. 7) show that the main deformation has a dominant SE component, with magnitude ranging from 2.5 to $10.9 \mathrm{~m}$ depending on the sector of the landslide.

The East-West component shows that the maximum displacement is located in the crown area. The values are negative because of the slope direction with respect to the LOS of the ascending orbit, varying between -10.9 and $-8.3 \mathrm{~m}$. Furthermore, in the central part of the landslide, southern than Villa Carosi, the 

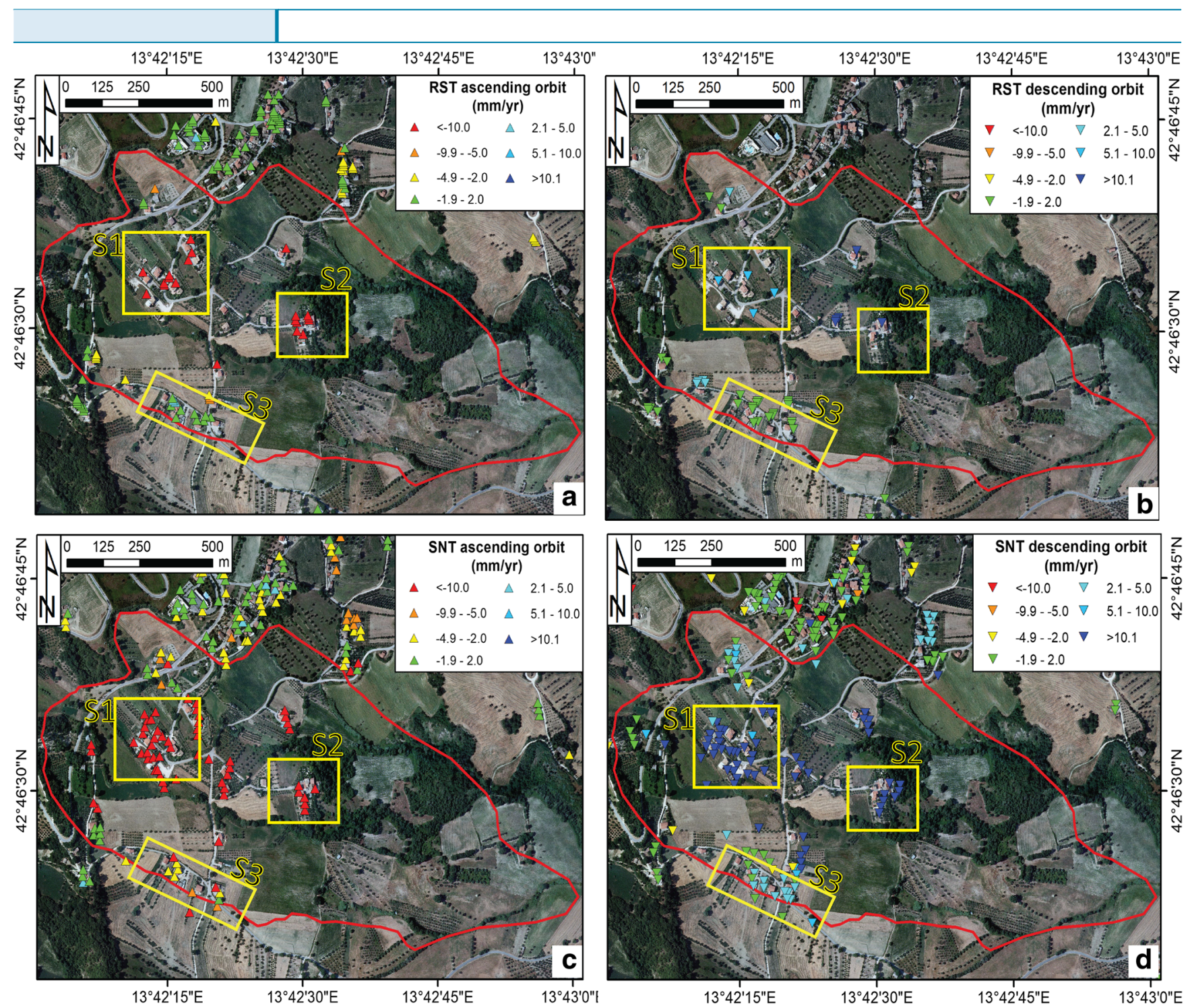

Fig. 5 SqueeSAR datasets for the area of interest. a Radarsat-2 ascending. b Radarsat-2 descending. $\mathbf{c}$ Sentinel-1 ascending $\mathbf{d}$ Sentinel-1 descending. The red contour defines the landslide perimeter. S1, S2, and S3 represent sectors of the landslide characterized by different LOS velocities

deformation values range from -9 to $-7.5 \mathrm{~m}$ (Fig. 7a). The minimum displacement is equal to $-2.5 \mathrm{~m}$, located in the toe area.

The North-South component exhibits a similar spatial distribution, with peaks of deformation in the crown area, where the azimuthal displacement ranges between -9.8 and $-8.0 \mathrm{~m}$ in the south direction (Fig. 7b). Analogous displacements, with the same component direction, are detected in the Villa Carosi area. The toe area shows lower North-South displacements (maximum values of $3.8 \mathrm{~m}$ ) in the North direction, index of a slight change in the main component of the movement.

\section{Discussion}

In this paper, an integrated SAR-based strategy was applied for obtaining information before and immediately after the 12th February 2017 landslide event. Considering its characteristics, the aim of this work was to integrate interferometric data, obtained from the SqueeSAR analysis of Radarsat-2 and Sentinel-1 data, with the rapid motion technique, which takes into consideration the amplitude rather than the phase information of a SAR image, allowing to derive the intense deformation field generated by the landslide. This approach is used to retrieve remotely sensed information about different displacement regimes, ranging from millimetric and centimetric deformation detected by the PSI technique, to the capability of detection of metric displacements by means of the RMT algorithm.

The SqueeSAR data gave a comprehensive view over a nine-year period before the landslide complete mobilization. The results showed that the northern part of the Ponzano village is stable (in the defined stability interval of $\pm 2 \mathrm{~mm}$ /year) considering both RST and SNT data. These results are in accordance with the ground observations (absence of landslide-related fissures or building damage) that led to the post-failure definition of the boundaries of the movement. On the other hand, the C-band data registered the presence of moving measurement points in the central sector (Sectors $S_{1}$ and $S_{2}$ in Fig. 5) of the future landslide perimeter. In particular, the SNT data show a clear acceleration of the deformation 


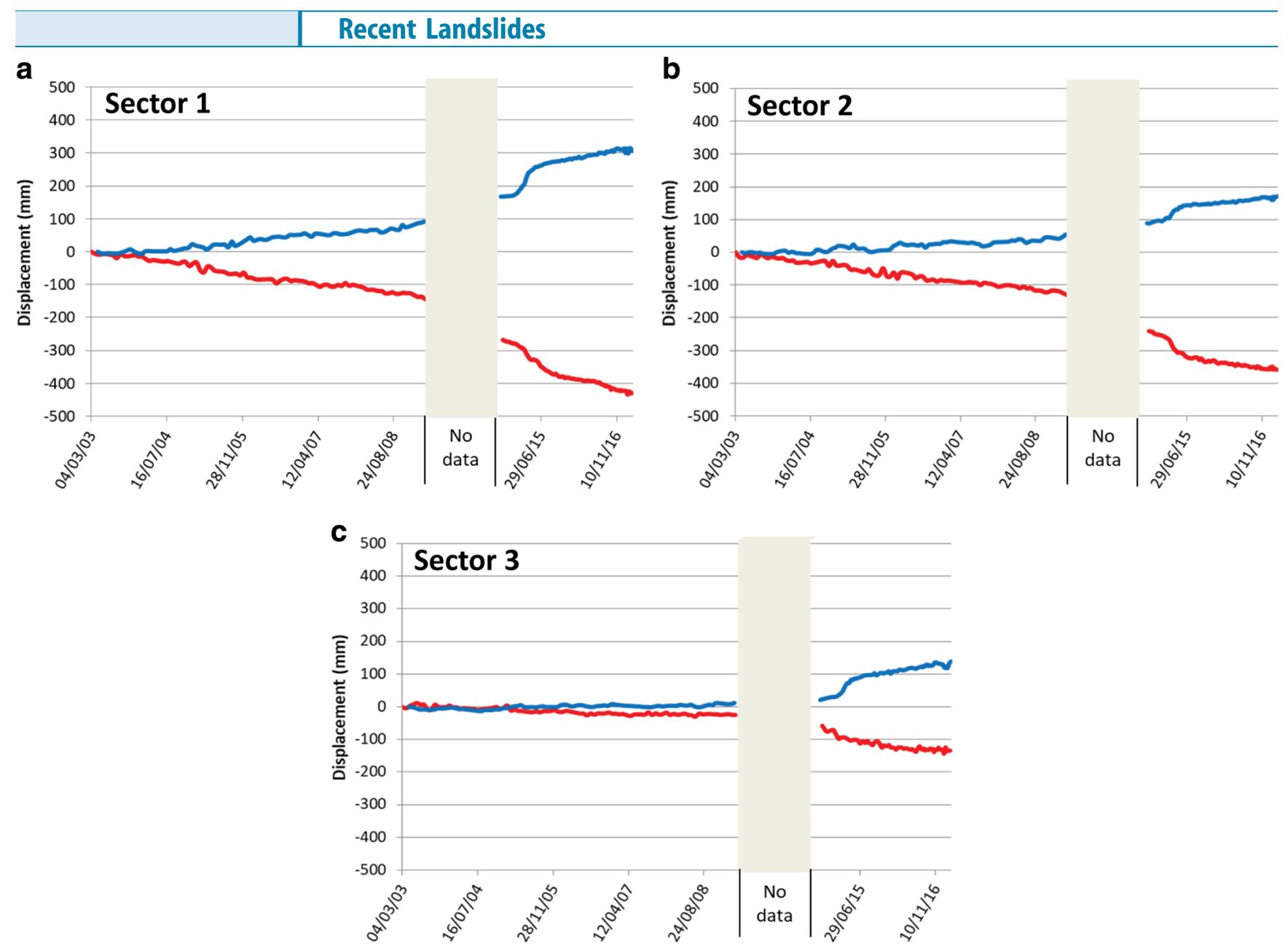

Fig. 6 Time series of deformation for the three sectors of the landslide. The blue and red lines represent the ascending and descending tracks, respectively. From 2003 to 2009, the time series are referred to the RST dataset, whereas from 2014 to 2017 are referred to the SNT dataset. a Sector 1 is the Villa Carosi hamlet. b Sector 2 is the group of buildings south-western than Ponzano village. $\mathrm{c}$ Sector $\mathrm{C}$ is the group of buildings along the southern border of the landslide
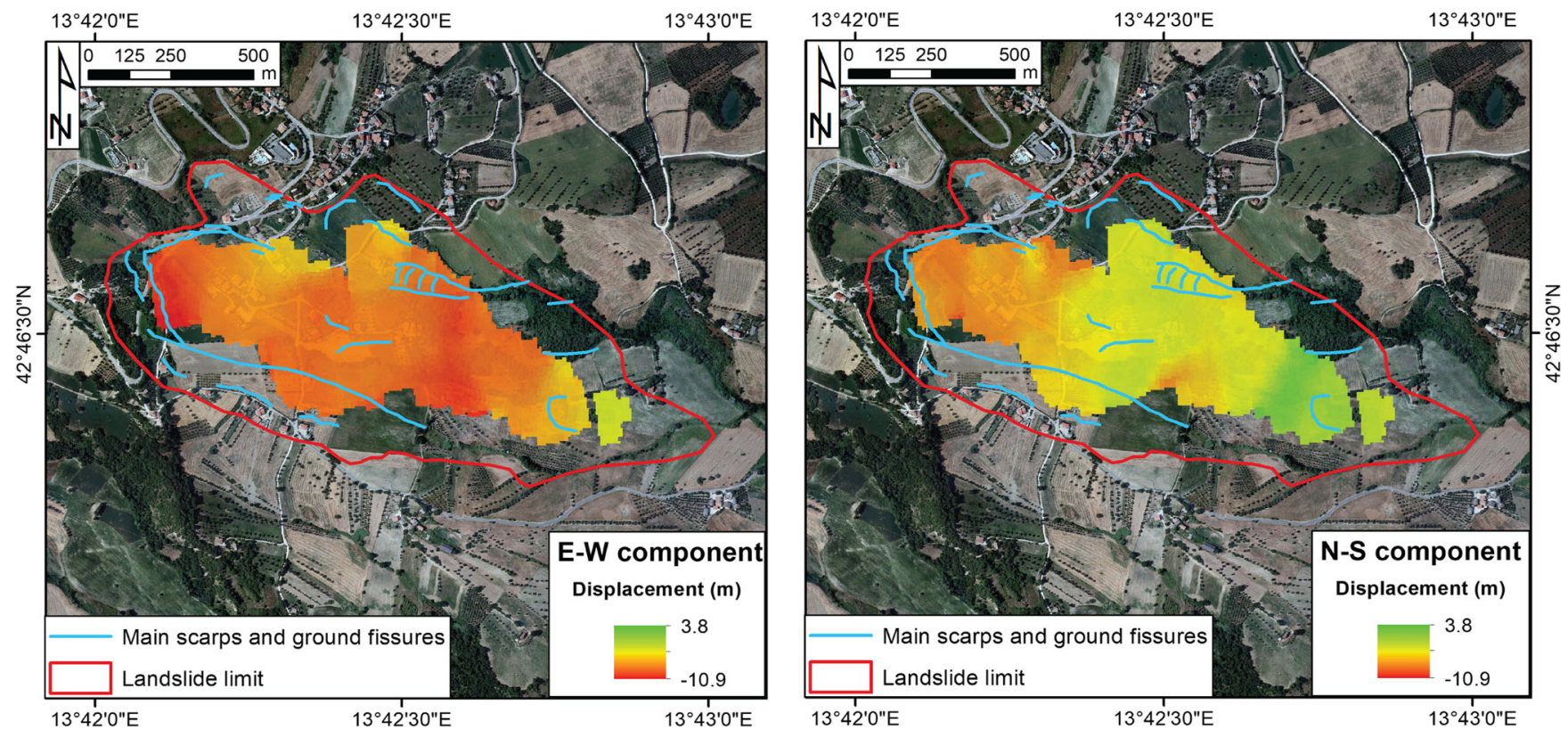

Fig. 7 Rapid motion tracking results for the landslide area. a East-West (range) and b North-South (azimuth) components 
trends with respect to the RST monitored period (March 2003March 2009). For example, the buildings of Villa Carosi recorded LOS mean velocities almost doubled between January 2014 and February 2017 (SNT acquisition) with respect to the 2003-2009 period (RST acquisition). In fact, the deformation rates increase from $15 \mathrm{~mm}$ /year to over $50 \mathrm{~mm}$ /year in both orbits. The maximum variability between the RST and SNT time series of deformation was registered by the buildings located along the southern boundary of the landslide body (Sector 3 in Fig. 6), where differences almost equal to one order of magnitude were detected. In this case, the average LOS velocities increase from $4 \mathrm{~mm}$ /year to over $40 \mathrm{~mm}$ /year in both orbits. These evidences suggest that the slope movement was already active almost 10 years before the landslide occurrence, recording very slow to slow displacements rates.

The velocity increase recorded by the SNT data is partially due to the high deformation rates recorded between the first days of January 2015 and mid-March 2015. This trend change is particularly evident in the Sector 1 and 3 time series. We interpret this abrupt variation, during the rainy and snowy winter months of this part of the Central Apennines, as a possible landslide intense acceleration that did not lead to a complete failure as in the case of the February 2017 event. In this sense, the recorded trend change can be seen as a precursor of the main landslide failure. Unfortunately, the Civitella del Tronto rain gauge was not installed at that time, not allowing a direct comparison with rain data.

It is noted that the official landslide catalogs (Hydrogeological Setting Plan of the Abruzzi Region and the IFFI catalogue), updated a few years ago, report a quiescent landslide for this area. This evidence shows the importance of the availability of PSI data for retrieving not only the deformation behavior of a landslide after an occurred event but also to update preexistent catalogs, providing useful information for urban planning and civil protection activities (Raspini et al. 2017).

The use of an amplitude-based InSAR analysis provided information on those areas where standard multi-interferometric approach may fail for the intrinsic characteristics of the phase signal. The exploitation of the RMT algorithm provides reliable results for evaluating the cumulative displacement induced by the landslide movement and the main direction of the displacement vector. In particular, the RMT results are in accordance with the contour of the landslide defined during the field campaign; the maximum displacement, registered in both range and azimuth directions, correspond to the crown area where the main landslide scarp was found. Moreover, another area that registered displacement values around 8-9 $\mathrm{m}$ is the central sector of the landslide (Villa Carosi hamlet), where the presence of the most damaged buildings was recorded during the field surveys. Considering the East-West and North-South components, the main displacement vector is along the SE direction, in accordance with the SqueeSAR results and with the morphology of the slope.

\section{Conclusions}

This work presented the InSAR characterization of the 12th February 2017 Ponzano complex landslide that affected part of this village of the Civitella del Tronto municipality (Abruzzi Region). The landslide mobilization, triggered by the concurrent effects of snow melting and intense rainfalls during the months of January and February 2017, damaged the road network and several private houses, that were subsequently evacuated.
An integrated strategy that combines phase-derived PSI (SqueeSAR algorithm) data and amplitude-derived RMT data has been proposed for evaluating the displacement pattern of the landslide before and immediately after its failure. The SqueeSAR analysis was performed using C-band SAR images acquired by the Canadian satellite Radarsat-2 and by the European sensor Sentinel-1; whereas, the RMT algorithm was applied to two images acquired by the German X-band satellite TerraSAR-X.

The results obtained show the capability of this type of strategy for deriving multi-temporal information from SAR sensors operating in different bands and analyzed exploiting different algorithms. In particular, the PSI data have been used to determine the state of activity of the landslide in a temporal interval of 9 years before the event, while the RMT data have been exploited to evaluate the deformation field induced by the landslide.

This paper demonstrates and confirms the usefulness of analyzing SAR images for post-failure landslide investigation, allowing to detect not only the deformation induced by the movement, but also to retrieve precursors of the phenomenon.

Finally, the InSAR analysis and its outputs can be successfully used not only as a post-emergency instrument but also for being implemented in risk management strategies at local, regional, and national level.

\section{Acknowledgements}

The authors thank the Italian Civil Protection Department for its support during the field survey and the helicopter recognizance. In addition, we are grateful to the entire Tre-Altamira staff for supporting all the data processing phases.

Open Access This article is distributed under the terms of the Creative Commons Attribution 4.0 International License (http:// creativecommons.org/licenses/by/4.0/), which permits unrestricted use, distribution, and reproduction in any medium, provided you give appropriate credit to the original author(s) and the source, provide a link to the Creative Commons license, and indicate if changes were made.

\section{References}

Bamler R, Eineder M (2005) Accuracy of differential shift estimation by correlation and split-bandwidth interferometry for wideband and delta-k SAR systems. IEEE Geosci Remote Sens 2:151-155. https://doi.org/10.1109/LGRS.2004.843203

Bardi F, Raspini F, Ciampalini A, Kristensen L, Rouyet L, Lauknes TR, Frauenfelder R, Casagli N (2016) Space-borne and ground-based InSAR data integration: the Åknes test site. Remote Sens 8:237. https://doi.org/10.3390/rs8030237

Béjar-Pizarro M, Notti D, Mateos RM, Ezquerro P, Centolanza G, Herrera G, Bru G, Sanabria M, Solari L, Duro J, Fernández J (2017) Mapping vulnerable urban areas affected by slow-moving landslides using Sentinel-1 InSAR data. Remote Sens 9:876. https://doi.org/10.3390/rs9090876

Bellotti F, Bianchi M, Colombo D, Ferretti A, Tamburini A (2014) Advanced InSAR techniques to support landslide monitoring. In: Mathematics of planet earth. Springer, Berlin, pp 287-290

Bianchini S, Herrera G, Mateos RM, Notti D, Garcia I, Mora 0, Moretti S (2013) Landslide activity maps generation by means of persistent scatterer interferometry. Remote Sens 5:6198-6222. https://doi.org/10.3390/rs5126198

Bianchini S, Ciampalini A, Raspini F, Bardi F, Di Traglia F, Moretti S, Casagli N (2015a) Multi-temporal evaluation of landslide movements and impacts on buildings in San Fratello (Italy) by means of C-band and X-band PSI data. Pure Appl Geophys 172:3043-3065. https://doi.org/10.1007/s00024-014-0839-2 
Bianchini S, Pratesi F, Nolesini T, Casagli N (2015b) Building deformation assessment by means of persistent scatterer interferometry analysis on a landslide-affected area: the Volterra (Italy) case study. Remote Sens 7:4678-4701. https://doi.org/10.3390/rs70404678

Brozzetti F, Boncio P, Lavecchia G (2010) Note illustrative della Carta Geologica d'Italia alla scala 1:50000, Foglio 339, Teramo. Ispra, Roma

Calvello M, Peduto D, Arena L (2016) Combined use of statistical and DInSAR data analyses to define the state of activity of slow-moving landslides. Landslides 14:473489. https://doi.org/10.1007/s10346-016-0722-6

Cantalamessa G, Di Celma C (2004) Sequence response to syndepositional regional uplift: insights from high-resolution sequence stratigraphy of late early Pleistocene strata, Periadriatic Basin, central Italy. Sediment Geol 164:283-309. https://doi.org/10.1016/ j.sedgeo.2003.11.003

Canuti P, Casagli N, Ermini L, Fanti R, Farina P (2004) Landslide activity as a geoindicator in Italy: significance and new perspectives from remote sensing. Environ Geol 45:907919. https://doi.org/10.1007/s00254-003-0952-5

Canuti P, Casagli N, Catani F, Falorni G, Farina P (2007) Integration of remote sensing techniques in different stages of landslide response. In: Sassa K, Fukuoka $H$, Wang $F$, Wang $G$ (eds) Progress in landslide science. Springer, Heidelberg, pp 251-260

Casagli N, Frodella W, Morelli S, Tofani V, Ciampalini A, Intrieri E, Raspini F, Rossi G, Tanteri L, Lu P (2017) Spaceborne, UAV and ground-based remote sensing techniques for landslide mapping, monitoring and early warning. Geoenviron Disasters 4:9. https://doi.org/10.1186/s40677-017-0073-1

Centamore E, Cantalamessa G, Micarelli A, Potetti M, Berti D, Bigi S, Morelli C, Ridolfi M (1991) Stratigrafia e analisi di facies dei depositi del Miocene e del Pliocene inferiore dell'avanfossa marchigiano-abruzzese e delle zone limitrofe. Studi Geol Camerti 11:125-131 special volume CROP

Ciampalini A, Raspini F, Lagomarsino D, Catani F, Casagli N (2016) Landslide susceptibility map refinement using PSInSAR data. Remote Sens Environ 184:302-315. https://doi.org/10.1016/j.rse.2016.07.018

Corsini A, Farina P, Antonello G, Barbieri M, Casagli N, Coren F, Guerri L, Ronchetti F, Sterzai P, Tarchi D (2006) Space-borne and ground-based SAR interferometry as tools for landslide hazard management in civil protection. Int J Remote Sens 27:23512369. https://doi.org/10.1080/01431160600554405

Crosetto M, Monserrat 0, Cuevas-González M, Devanthéry N, Crippa B (2016) Persistent scatterer interferometry: a review. ISPRS J Photogramm Remote Sens 115:78-89. https://doi.org/10.1007/978-1-4020-9428-6_3

Cruden DM, Varnes DJ (1996) Landslide types and processes. In: Turner AK, Schuster RL (eds) Landslides investigation and mitigation. In: Transportation research board, US National Research Council. Special Report 247. Washington, DC, pp 36-75

De Zan F (2014) Accuracy of incoherent speckle tracking for circular Gaussian signals. IEEE Geosci Remote Sens Lett 11:264-267. https://doi.org/10.1109/lgrs.2013.2255259

Del Soldato M, Bianchini S, Calcaterra D, De Vita P, Di Martire D, Tomás R, Casagli N (2017) A new approach for landslide-induced damage assessment. Geomat Nat Haz Risk 8:1524-1537. https://doi.org/10.1080/19475705.2017.1347896

Farina P, Casagli N, Ferretti A (2007) Radar-interpretation of InSAR measurements for landslide investigations in civil protection practices. In: Proceedings of 1st North American landslide conference, Vail, Colorado, pp 272-283

Ferretti A, Prati C, Rocca F (2001) Permanent scatterers in SAR interferometry. IEEE Trans Geosci Remote Sens 39:8-20. https://doi.org/10.1109/36.898661

Ferretti A, Fumagalli A, Novali F, Prati C, Rocca F, Rucci A (2011) A new algorithm for processing interferometric data-stacks: SqueeSAR. IEEE Trans Geosci Remote Sens 49:3460-3470. https://doi.org/10.1109/tgrs.2011.2124465

Herrera G, Notti D, García-Davalillo JC, Mora 0, Cooksley G, Sánchez M, Arnaud A, Crosetto M (2011) Analysis with C-and X-band satellite SAR data of the Portalet landslide area. Landslides 8:195-206. https://doi.org/10.1007/s10346-010-0239-3

Herrera G, Gutiérrez F, García-Davalillo JC, Guerrero J, Notti D, Galve JP, FernándezMerodo JA, Cooksley G (2013) Multi-sensor advanced DInSAR monitoring of very slow landslides: the Tena Valley case study (central Spanish Pyrenees). Remote Sens Environ 128:31-43. https://doi.org/10.1016/j.rse.2012.09.020

Lu P, Catani F, Tofani V, Casagli N (2014) Quantitative hazard and risk assessment for slow-moving landslides from persistent scatterer interferometry. Landslides 11:685696. https://doi.org/10.1007/s10346-013-0432-2

Mattei M, Funiciello R, Kissel C (1995) Paleomagnetic and structural evidence for Neogene block rotations in the Central Apennines, Italy. J Geophys Res 100:863883. https://doi.org/10.1029/95jb00864

Meisina C, Zucca F, Notti D, Colombo A, Cucchi A, Savio G, Giannico C, Bianchi M (2008) Geological interpretation of PSInSAR data at regional scale. Sensors 8:7469-7492. https://doi.org/10.3390/s8117469
Nadim F, Kjekstad 0, Peduzzi P, Herold C, Jaedicke C (2006) Global landslide and avalanche hotspots. Landslides 3:159-173. https://doi.org/10.1007/s10346-006-0036-1

Nisio S, Prestininzi A, Scarascia Mugnozza G (1996) I calanchi del settore settentrionale della fascia periadriatica abruzzese: quadro morfotettonico e loro caratterizzazione. Studi Geol Camerti 14:29-46

Notti D, Herrera G, Bianchini S, Meisina C, García-Davalillo JC, Zucca F (2014) A methodology for improving landslide PSI data analysis. Int J Remote Sens 35:2186-2214

Oliveira SC, Zêzere JL, Catalão J, Nico G (2015) The contribution of PSInSAR interferometry to landslide hazard in weak rock-dominated areas. Landslides 12:703-719. https://doi.org/10.1007/s10346-014-0522-9

Pagliara P, Basile G, Cara P, Corazza A, Duro A, Manfrè B, Onori R, Proietti C, Sansone V (2014) Integration of earth observation and ground-based HR data in the civil protection emergency cycle: the case of the DORIS project. In: Mathematics of planet earth. Springer, Berlin, pp 263-266

Paradella WR, Ferretti A, Mura JC, Colombo D, Gama FF, Tamburini A, Santos AR, Novali F, Galo M, Camargo PO, Silva AQ, Silva GG, Silva A, Gomes LL (2015) Mapping surface deformation in open pit iron mines of Carajás Province (Amazon region) using an integrated SAR analysis. Eng Geol 193:61-78. https://doi.org/10.1016/ j.enggeo.2015.04.015

Raspini F, Ciampalini A, Del Conte S, Lombardi L, Nocentini M, Gigli G, Ferretti A, Casagli N (2015) Exploitation of amplitude and phase of satellite SAR images for landslide mapping: the case of Montescaglioso (South Italy). Remote Sens 7:14576-14596. https://doi.org/10.3390/rs71114576

Raspini F, Bardi F, Bianchini S, Ciampalini A, Del Ventisette C, Farina P, Ferrigno F, Solari L, Casagli N (2017) The contribution of satellite SAR-derived displacement measurements in landslide risk management practices. Nat Hazards 86:327-351. https:// doi.org/10.1007/s11069-016-2691-4

Salvati P, Rossi M, Bianchi C, Guzzetti F (2015) Landslide risk to the population of Italy and its geographical and temporal variations. In: Chavez M, Ghil M, Urrutia-Fucugauchi J (eds) Extreme events: observations, modeling, and economics. Wiley, Hoboken

Solari L, Barra A, Herrera G, Bianchini S, Monserrat 0, Béjar-Pizarro M, Crosetto M, Sarro $\mathrm{R}$, Moretti $\mathrm{S}$ (2017). Fast detection of ground motions on vulnerable elements using Sentinel-1 InSAR data. Geomat Nat Haz Risk 9:152-174. https://doi.org/10.1080/ 19475705.2017.1413013

Speranza F, Sagnotti L, Mattei M (1997) Tectonics of the Umbria-Marche-Romagna Arc (central northern Apennines, Italy): new paleomagnetic constraints. J Geophys Res Solid Earth 102:3153-3166. https://doi.org/10.1029/96jb03116

Tomás R, Li Z, Lopez-Sanchez JM, Liu P, Singleton A (2016) Using wavelet tools to analyse seasonal variations from InSAR time-series data: a case study of the Huangtupo landslide. Landslides 13:437-450. https://doi.org/10.1007/s10346-015-0589-y

Tralli DM, Blom RG, Zlotnicki V, Donnellan A, Evans DL (2005) Satellite remote sensing of earthquake, volcano, flood, landslide and coastal inundation hazards. ISPRS J Photogramm Remote Sens 59:185-198. https://doi.org/10.1016/j.isprsjprs.2005.02.002

Varnes DJ (1978) Slope movement types and processes. In: Schuster RL, Krizek RJ (eds) Landslides, analysis and control, special report 176: transportation research board, National Academy of Sciences, Washington, DC., pp 11-33

Vergni L, Di Lena B, Chiaudani A (2016) Statistical characterisation of winter precipitation in the Abruzzo region (Italy) in relation to the North Atlantic Oscillation (NAO). Atmos Res 178:279-290. https://doi.org/10.1016/j.atmosres.2016.03.028

L. Solari $(\bowtie) \cdot$ F. Raspini - M. Del Soldato - S. Bianchini - F. Ferrigno •

N. Casagli

Earth Sciences Department,

University of Firenze,

Via La Pira 4, Firenze, Italy

Email: Iorenzo.solari@unifi.it

\section{A. Ciampalini}

Earth Sciences Department,

University of Pisa,

Via Santa Maria 53, Pisa, Italy

S. Tucci

Engineering Geologist,

Studio Geologico Tucci,

Civitella del Tronto, 64010, Italy 